\title{
Penerapan Pembelajaran Daring Menggunakan LMS (Google Classroom Dan Quiper) Untuk Meningkatkan Hasil Belajar Fisika Pada Materi Gerak Harmonis Siswa Kelas X MIPA 2 Semester Genap SMA Negeri 1 Ngemplak Boyolali Tahun Pelajaran 2019/ 2020
}

\author{
Bangun Sartono \\ Guru Fisika SMA Negeri 1 Ngemplak Boyolali ; Jl. Embarkasi Haji Donohudan Ngemplak Boyolali \\ Email: bang.sartono1973@gmail.com
}

\begin{abstract}
The objectives of this study were: 1) to describe the online learning process (on line) in the physics subject by applying the use of the google classroom and quiper learning management system $(L M S), 2)$ to describe the improvement of learning outcomes in physics. This research was conducted using classroom action research which was designed through two cycles with procedures for planning, implementing actions, observing, and reflecting in each cycle. This research activity was carried out in the even semester of the 2019/2020 school year, with the research subjects of class X MIPA 2 semester 2 SMA N 1 Ngemplak in the 2019/2020 school year. The data needed in this study were obtained through test and non-test techniques. The non-test technique is in the form of direct observation / observation of students when on line learning activities take place both in the first cycle and the second cycle, using the assessment instruments that have been provided. While the test technique is in the form of an on line test which is carried out after each cycle ends. From the results of research on learning activities in the network (online / on line) that have been carried out for two cycles and based on all the discussions and analyzes that have been carried out, it can be concluded that: The application of online learning using the Learning Management System (Google Classroom and Quiper) can improve the results. learning physics in the material of harmonious motion for students of class X MIPA 2 even semester SMA Negeri 1 Ngemplak Boyolali in the academic year 2019/2020. The average value of students in cycle I increased by 10.51 or $17.37 \%$, from 60.51 to 71,02 , and increased again in cycle II of 15.38 or $25.42 \%$, namely 71.02 to 75.90 , and included in the good category
\end{abstract}

Keywords: Online Learning, Learning Management System, Physics Learning, and Harmonious Motion

\begin{abstract}
Abstrak : Tujuan penelitian ini adalah : 1) mendeskripsi proses pembelajaran daring (on line) mata pelajaran Fisika dengan menerapkan penggunaan LMS (learning management system) google classroom dan quiper, 2) mendeskripsi peningkatan hasil belajar Fisika. Penelitian ini dilaksanakan dengan menggunakan penelitian tindakan kelas yang dirancang melalui dua siklus dengan prosedur perencanaan, pelaksanaan tindakan, pengamatan, dan refleksi dalam tiap-tiap siklus. Kegiatan penelitian ini dilakukan pada semester genap tahun pelajaran 2019/2020, dengan subyek penelitian siswa kelas X MIPA 2 semester 2 SMA N 1 Ngemplak tahun pelajaran 2019/2020. Data-data yang diperlukan dalam penelitian ini diperoleh melalui teknik tes dan non tes. Teknik non tes berupa observasi/ pengamatan langsung pada siswa saat kegiatan pembelajaran on line berlangsung baik pada siklus pertama maupun siklus kedua, dengan menggunakan instrumen penilaian yang telah disediakan. Sedangkan teknik tes berupa tes on line yang dilakukan setelah tiap-tiap siklus berakhir. Dari hasil penelitian kegiatan pembelajaran dalam jaringan ( daring/on line) yang telah dilakukan selama dua siklus dan berdasarkan seluruh pembahasan serta analisis yang telah dilakukan dapat disimpulkan bahwa : Penerapan pembelajaran daring menggunaan Learning Management System (google classroom dan quiper) dapat meningkatkan hasil belajar fisika pada materi gerak harmonis siswa kelas X MIPA 2 semester genap SMA Negeri 1 Ngemplak Boyolali tahun pelajaran 2019/ 2020. Nilai rata-rata siswa pada siklus I mengalami peningkatan sebesar 10,51 atau $17,37 \%$ yaitu dari 60,51 menjadi 71,02 , dan mengalami peningkatan lagi pada siklus II sebesar 15,38 atau $25,42 \%$ yaitu 71,02 menjadi 75,90 , dan termasuk dalam kategori baik.
\end{abstract}


Kata kunci : Pembelajaran Daring, Learning Manajemen System, Pembelajaran Fisika, dan Gerak Harmonis

\section{PENDAhuluan}

Pada masa pandemi seperti ini, sistem pembelajaran konvensional mulai tidak digunakan. Hal ini sebagai salah satu upaya dalam pencegahan dan penyebaran Covid - 19. Sistem pembelajaran konvensional yang dilaksanakan diganti dengan pembelajaran daring dengan menggunakan berbagai aplikasi pembelajaran daring yang dapat memberi ruang interaksi antara guru dan siswa tanpa harus bertatap muka. Pengajar, siswa, dan orang tua dituntut untuk menyesuaikan diri secara cepat dan efektif pada sistem pembelajaran ini. Ditengah situasi Pandemi ini, metode daring dirasa menjadi jalan keluar yang paling tepat untuk dilakukan sebagai jawaban atas tuntutan dalam proses pembelajaran agar dapat terlaksana. Walaupun demikian pada kondisi normal, banyak celah kekurangan dari metode daring ini. Pengetahuan dan kemampuan guru dalam penguasaan teknologi, juga Pengetahuan dan kemampuan siswa maupun orang tua menjadi salah satu kendala dalam penerapan sistem daring ini. Meskipun demikian guru harus meningkatkan skill atau kemampuan pembelajaran daring, dan cepat beradaptasi untuk menguasai berbagai aplikasi yang mendukung pembelajaran daring.

Dampak pandemi Covid - 19 juga berlaku pada pembelajaran Fisika. Pemahaman konsep yang ditanamkan sebagai kemampuan dalam memahami konsep dan fenomena gejala alam juga ikut terdamapak. Padahal pemahaman konsep merupakan bagian yang sangat penting dalam pembelajaran Fisika. Pemahaman siswa terhadap konsep Fisika merupakan salah satu tujuan pembelajaran Fisika yang harus dicapai. Dalam mempelajari Fisika peserta didik harus memahami konsep agar dapat menyelesaikan permasalahan fisika dan mampu mengaplikasikan pembelajaran tersebut didunia nyata. Pemahaman terhadap konsep Fisika merupakan dasar untuk belajar Fisika secara bermakna. Mata pelajaran Fisika merupakan mata pelajaran yang dianggab sulit. Hal ini karena siswa merasa kurang senang dengan mata pelajaran Fisika sehingga perlu menambah motivasi dan semangat belajar. Dengan semangat belajar tinggi akan memperoleh nilai yang baik, namun kenyataannya dari hasil evaluasi yang diberikan topik sebelumnya masih banyak siswa yang mendapat nilai di bawah KKM yang ditentukan. Selain itu pada proses kegiatan belajar mengajar mata pelajaran Fisika siswa masih kurang termotivasi dalam belajar. Masalah-masalah tersebut membuktikan bahwa dalam hasil pelaksanaan proses pembelajaran Fisika pada umumnya sering mengalami kesulitan didalam memahami materi yang diberikan guru. Bagi guru kesulitannya muncul saat melatih siswa agar benar-benar mengerti dan dapat tergali potensinya. Sedangkan bagi siswa kesulitannya muncul karena sebagian besar peserta didik menganggap bahwa mata pelajaran Fisika merupakan pelajaran yang sulit dipelajari, tidak menarik dan membosankan. Kondisi ini diperparah dengan adanya anggapan bahwa mata pelajaran Fisika akan terlaksana dengan sempurna bila siswa mempunyai bakat dan minat. Kesulitan penguasaan materi mata pelajaran Fisika mengisyaratkan adanya permasalahan yang perlu segera dicari jalan keluarnya. Kenyataan tersebut menunjukkan bahwa prestasi siswa pada mata pelajaran Fisika terdapat masalah berupa hasil belajar mata pelajaran Fisika sebagian besar siswa sebanyak 75\% belum mencapai KKM yang ditentukan dan hanya $25 \%$ yang dapat menguasai materi dengan baik. Permasalahan ini perlu segera diatasi agar dapat meningkatkan prestasi hasil belajar siswa pada mata pelajaran Fisika.

Dalam pembelajaran Fiska (1). Proses pembelajaran daring yang dilakukan pada materi khususnya Gerak Harmonis belum secara optimal menunjukkan peran serta/keaktifan siswa, dan guru belum menggunakan metode yang tepat, sebelumnya pembelajaran daring pada mata pelajaran Fisika khususnya materi Gerak harmonis, dilaksanakan menggunakan metode 
pembelajaran dengan menggunakan watshapp yang sangat sederhana. (2). Pelaksanaan bimbingan yang dilakukan oleh guru terhadap siswa terlihat kurang efektif. Hal ini terjadi karena dalam waktu yang bersamaan guru harus membimbing banyak siswa. Sehingga hanya sebagian kecil peserta didik yang betul-betul mendapatkan bimbingan, sedangkan sebagian yang lain juga mendapatkan bimbingan namun kurang intensif. (3) Hasil evaluasi akhir menunjukkan bahwa prestasi belajar Fisika sebagian besar hasilnya belum memuaskan yaitu $75 \%$ yang mendapat nilai dibawah KKM yang ditentukan yaitu 70 , sementara materi ini merupakan materi dasar untuk mempelajari materi Fisika selanjutnya. Selanjutnya dari latar belakang tersebut maka perlu pemecahan berupa penelitian untuk meningkatkan kualitas pembelajaran yaitu Penelitian Tindakan Kelas.

\subsection{Pengertian Model Pembelajaran Daring dengan Learning Management System (LMS) Google Classroom dan Quiper}

Menurut KBBI Kemendikbud, daring adalah akronim dari dalam jaringan. Artinya terhubung melalui jejaring komputer, internet, dan sebagainya. Merinci kegiatan-kegiatan daring di antaranya, webinar, kelas online. Seluruh kegiatan dilakukan menggunakan jaringan internet dan komputer. Pembelajaran daring adalah metode belajar yang menggunakan model interaktif berbasis internet dan Learning Manajemen System (LMS), seperti menggunakan Google Classroom, Quiper, Zoom, Google Meet, dan lainnya.

Sistem Pembelajaran daring sebenarnya bukanlah hal yang betul betul baru. Dalam dunia pembelajaran, sistem ini telah banyak digunakan. Metode pembelajaran daring ini dapat dijadikan salah satu metode yang telah terbukti mampu mengoptimalkan hasil belajar. Ada beberapa prinsip yang digunakan dalam metode pembelajaran daring ini. Prinsip prinsip dalam pembelajaran daring :

1. Mengatur jadwal belajar dengan tepat dan disiplin dengan waktu yang telah ditentukan.

2. Menghilangkan fikiran dari hal-hal yang bisa memecah konsentrasi saat belajar daring.

3. Menyediakan waktu khusus untuk mengerjakan tugas-tugas yang diberikan, dan konsisten untuk melakukannya.

4. Memastikan peralatan yang diperlukan untuk belajar daring dalam kondisi prima, agar konsentrasi belajar terjaga.

5. Menutup akses sosial media, layanan video, atau aplikasi yang bisa mengganggu konsentrasi saat belajar daring.

Kegiatan belajar mengajar jarak jauh tanpa bertatap muka dapat menggunakan sejumlah platform digital. Salah satunya adalah Google Clasroom yang banyak digunakan oleh tenaga pengajar di seluruh dunia untuk menyampaikan materi belajar hingga menyelenggarakan ujian secara daring. Platform tersebut tidak memungut biaya sepeser pun kepada penggunanya, baik tenaga pengajar maupun murid yang menerima materi atau mengikuti ujian.

Namun, ada beberapa persyaratan yang harus dipenuhi bagi mereka yang ingin menggunakan Google Classroom. Tentunya yang pertama adalah memiliki akun Google. Kemudian terdapat pula batas minimal umur pengguna Google Classroom yang akan membuat kelas. Pengguna platform tersebut harus berusia 13 tahun atau lebih.

Siswa dapat membuat kelas menggunakan Akun Google pribadi. Namun, jika sekolah memiliki akun G Suite for Education, siswa harus menggunakan email tersebut untuk membuat kelas. Google Classroom tersedia untuk perangkat desktop atau laptop dengan menggunakan web. Adapun untuk perangkat seluler berbasis Android atau iOS bisa menggunakan aplikasi. Saat ini, aplikasi Google Classroom sudah diunduh lebih dari 50 juta pengguna perangkat Android di seluruh dunia. Tenaga pengajar bisa mengelola semua dokumen yang dibutuhkan murid dalam pembelajaran. Dokumen pembelajaran dapat disimpan di Google Drive dan dapat 
diedit di aplikasi Drive, seperti Google Documents, Spreadsheet, dan sebagainya. Selain itu, Google Classroom memungkinkan komunikasi antara tenaga pengajar dengan murid atau antarmurid lebih efektif. Pengajar dapat membuat tugas, mengirim pengumuman, dan memulai diskusi kelas secara langsung. Adapun, murid-murid dapat berbagi materi antara satu sama lain dan berinteraksi di dalam kelas atau melalui surel. Tenaga pengajar juga bisa melihat dengan cepat siapa saja yang sudah dan belum menyelesaikan tugas, serta langsung memberikan nilai dan masukan real-time. Google Classroom terjangkau dan aman yang disediakan gratis untuk sekolah, lembaga nonprofit, dan perorangan serta tidak berisi iklan dan tidak pernah menggunakan konten pengguna atau data siswa untuk tujuan periklanan.

Selain itu, LMS yang banyak digunakan adalah Quipper School. Quipper School adalah learning management system tanpa biaya (gratis). Ini disediakan Quipper Indonesia untuk membantu guru dan siswa agar dapat melaksanakan kegiatan belajar mengajar secara efektif secara online. Sama halnya pembelajaran di sekolah, guru berperan sebagai fasilitator dalam mengelola materi, melaksanakan tes atau ujian, serta melihat perkembangan siswa. Siswa pun dapat dengan mudah mengerjakan pekerjaan rumah, tugas, hingga ujian secara online. Melalui platform ini, guru dapat mengirim dan mengelola materi pembelajaran, ujian, serta nilai. Siswa dapat mengerjakan pekerjaan rumah, tugas, dan ujian secara online dengan mudah. Agar kegiatan belajar mengajar dengan Quipper School dapat menjadi lebih efektif. Mari mulai mengetahui fitur-fitur apa saja yang terdapat dalam learning management system Quipper School. Berikut 3 fitur (portal) utama Quipper School yaitu QLink (Portal Guru). Portal ini diperuntukkan untuk membantu guru mengelola kelas dengan mengirimkan tugas dan materi yang akan diberikan kepada siswa. Selain itu, guru akan mendapatkan kemudahan dalam mengelola nilai siswa, hasil pekerjaan siswa secara otomatis tanpa harus mengoreksi setiap jawaban siswa secara manual. Selanjutnya QCreate (Portal Pembuatan Konten) memberikan keleluasaan guru dalam pembuatan soal ataupun materi sesuai dengan kebutuhan. Bahkan dapat dipublikasikan pada akun Quipper pribadinya. QLearn (Portal Siswa) diperuntukkan khusus untuk siswa dalam mengerjakan tugas dan menerima materi yang diberikan guru. Merebaknya kasus pandemi Covid-19 mengharuskaan semua proses kegiatan belajar mengajar bagi peserta didik dilakukan di rumah. Guna meminimalisir kontak fisik secara masal sehingga memutus mata rantai penyebaran virus. Pemerintah juga mengambil kebijakan pembelajaran jarak jauh dengan media daring (dalam jaringan), baik menggunakan ponsel, PC, atau laptop. Dari sinilah kemudian muncul aplikasi pembelajaran online salah satunya Quipper School Indonesia sebagai aplikasi terlengkap dalam menampilkan konten-konten materi pembelajaran sesuai kurikulum yang digunakan sekolah. Bahkan guru dimudahkan dengan adanya fitur penilaian dan analisis hasil belajar siswa yang bisa diunduh dan langsung dikirim melalui email guru. Saat pandemi covid-19 ini, siswa dan guru sangat terbantu dengan aplikasi Quipper School Indonesia. Bahkan banyaknya tugas dari guru, seringkali menjadi keluhan dalam pembelajaran daring. Beban belajar peserta didik tentunya harus diperhitungkan, terukur, baik secara materi maupun waktu. Tentunya perlu diingat bahwa pembelajaran di kelas tidak setiap saat diisi dengan tugas atau mengerjakan soal dalam jumlah banyak. Guru bisa memberikan tugas mengamati, mencoba, dan menganalis, sehingga lebih menarik dan menantang. Keberhasilan pembelajaran daring tersebut perlu adanya kerjasama sinergis antara guru, sekolah, orang tua, dan peserta didik. Sekolah perlu menaruh kepedulian kepada orang tua peserta didik yang tidak mampu membeli kuota atau tidak memiliki ponsel memadai dengan memfasilitasi, agar pembelajaran daring bisa berjalan optimal. 


\subsection{Kelebihan dan Kekurangan Model Pembelajaran Daring}

Dengan pembelajaran daring guru dapat menjadi fasilitator yang efektif. Hal itu bisa dilakukan secara virtual, dapat menggunakan kamera baik bagi guru maupun siswa, dan mikrofon untuk memfasilitasi interaksi yang sama. Sehingga guru seakan hadir secara fisik di ruangan virtual itu. Manfaat lain, siswa yang tidak hadir dapat melihat rekaman video pembelajaran dan juga siswa yang hadir juga dapat menontonnya berkali kali untuk menambah pemahaman mereka.

\subsection{Ada beberapa kelebihan saat menggunakan pembelajaran daring ini, yaitu :}

1. Waktu dan tempat lebih efektif. Siswa bisa langsung mengikuti proses belajar dari rumah.

2. Siswa tidak hanya bergantung pada guru, tapi juga bisa belajar untuk melakukan riset sendiri melalui internet.

3. Otomatis siswa dilatih untuk lebih menguasai teknologi informasi yang terus berkembang.

4. Menumbuhkan kesadaran pada siswa bahwa gawai bisa digunakan untuk hal-hal yang lebih produktif dan mencerdaskan.

5. Merupakan media komunikasi yang efektif, cepat dan kredibel untuk menyampaikan materi dari guru

\subsection{Beberapa kekurangan pelaksanaan pembelajaran daring yaitu :}

1. Sulit untuk mengontrol mana siswa yang serius mengikuti pelajaran dan mana yang tidak.

2. Pembelajaran lebih banyak bersifat teoretis dan minim praktik karena tidak dimungkinkan adanya interaksi langsung dengan siswa.

3. Bagi mereka yang tinggal di lokasi yang infrastruktur komunikasinya masih kurang baik tentu akan kesulitan untuk mengakses internet.

4. Tidak semua siswa memiliki dan mampu mengakses peralatan yang dibutuhkan (entah itu komputer, laptop, atau gawai lainnya) untuk pembelajaran online.

5. Terlalu banyak distraksi yang bisa mengganggu konsentrasi siswa saat belajar.

\subsection{Langkah-langkah Pembelajaran Daring}

Sebelum melaksanakan Pembelajaran Daring, kita perlu langkah dalam menyiapkan pembelajaran Daring. Langkah tersebut adalah sebagai berikut:

1. Siswa dan Guru merasa senang selama pembelajaran Daring, jangan sampai stres. Selain itu, perlu juga dipastikan bahwa semua pihak paham mengoperasikan perangkat maupun aplikasi yang digunakan sebagai sarana pembelajaran.

2. Kelas menjadi kelompok Belajar yang kecil, diskusi kelompok akan membuat waktu belajarnya lebih efektif .

3. Guru dan siswa harus sepakat mengerjakan tugas kelompok dan menciptakan tantangan berupa kuis yang memerlukan kolaborasi tim.

4. Alokasi waktu bagi siswa yang tertinggal atau kurang dapat memahami sesi pembelajaran. Pastikan semua siswa sudah hampir sama pemahaman terhadap subjek yang diajarkan.

5. Guru diharapkan fokus mengajarkan subjek pembelajaran yang dapat membantu kemampuan para siswa agar memahami pelajaran manapun.

\section{Kerangka Berpikir}

Berdasarkan latar belakang dan landasan teori di atas maka dapat dirumuskan kerangka berpikir dalam penelitian ini adalah sebagai berikut: (1). Proses pembelajaran daring yang dilakukan pada materi Gerak Harmonis pada masa pandemi Covid - 19 harus melibatkan peran 
serta/keaktifan siswa, dan guru belum menggunakan metode yang tepat, selama ini pembelajaran dilaksanakan dengan menggunakan metode pembelajaran daring dengan whatsap. (2). Pelaksanaan bimbingan yang dilakukan oleh guru terhadap peserta didik terlihat kurang efektif. Hal ini terjadi karena dalam waktu yang bersamaan guru harus membimbing banyak siswa. Sehingga hanya sebagian kecil peserta didik yang betul-betul mendapatkan bimbingan secara efektif, sedangkan sebagian yang lain juga mendapatkan bimbingan namun kurang intensif. (3). Hasil evaluasi akhir menunjukkan bahwa prestasi belajar Fisika sebagian besar hasilnya belum memuaskan yaitu $75 \%$ yang mendapat nilai dibawah KKM yang ditentukan (70), sementara materi ini penting sebagai materi dasar untuk materi selanjutnya.

\subsection{Hipotesis Tindakan}

Hipotesis yang diajukan dalam penelitian ini adalah: 1). Penerapan pembelajaran daring menggunaan LMS (google classroom dan quiper) dapat meningkatkan hasil belajar fisika pada materi gerak harmonis siswa kelas X MIPA 2 semester genap SMA Negeri 1 Ngemplak Boyolali tahun pelajaran 2019/2020. 2. Penerapan pembelajaran daring menggunaan LMS google classroom dan quiper dapat meningkatkan Prestasi belajar fisika pada materi gerak harmonis siswa kelas X MIPA 2 semester genap SMA Negeri 1 Ngemplak Boyolali tahun pelajaran 2019/2020. 3). Penerapan pembelajaran daring menggunaan LMS (google classroom dan quiper) dapat meningkatkan perubahan perilaku positif siswa kelas X MIPA 2 SMA Negeri 1 Ngemplak Boyolali setelah melaksanakan pembelajaran Fisika.

\section{METODE PENELITIAN}

Penelitian dilakukan di kelas X MIPA 2 SMA Negeri 1 Ngemplak Boyolali, dengan alamat Jalan Embarkasi Haji Donohudan Ngemplak Boyolali. Waktu penelitian dimulai bulan April 2020 sampai dengan Juni 2020 dengan kegiatan penyusunan proposal dan pembuatan instrumen penelitian, penelitian dan pengambilan data, pengolahan data dan penyusunan laporan hasil penelitian.

Subjek penelitian ini adalah siswa kelas X MIPA 2 SMA Negeri 1 Ngemplak Boyolali tahun pelajaran 2019/2020, dengan jumlah 39 siswa, yang terdiri 15 siswa laki-laki dan 24 siswa perempuan. Peneliti memilih Kelas X MIPA 2 sebagai subjek penelitian karena faktor-faktor berikut (1) Siswa kelas X MIPA 2 mengalami kesulitan dalam pembelajaran Fisika (2) adanya karakter yang perlu diperbaiki pada siswa kelas X MIPA 2 dalam pembelajaran Fisika.

\section{HASIL PENELITIAN DAN PEMBAHASAN}

\subsection{Deskripsi Kondisi Awal}

Hasil tes prasiklus diperoleh berdasarkan hasil tes tertulis sebelum dilaksanakan pembelajaran Fisika dengan menerapkan pembelajaran daring menggunaan LMS google classroom dan quiper, hasil tes prasiklus berfungsi untuk mengetahui kemampuan dasar siswa dalam mata pelajaran Fisika. Kondisi awal dalam penelitian ini dijumpai adanya permasalahan belajara siswa kelas X MIPA 2 SMA Negeri 1 Ngemplak Boyolali tahun pelajaran 2019/2020 dalam mengerjakan soal Gerak Harmonis. Siswa merasa kesulitan dalam mengerjakan soalsoal tersebut. Hasil belajar pada kondisi awal yang telah dilaksanakan dapat dilihat pada tabel berikut: 
Tabel 1. Hasil Tes Tertulis Fisika pada Prasiklus

\begin{tabular}{llllll}
\hline 1. & & 2. & Prasiklus & 3. & $\%$ \\
\hline 4. & Rata rata & 5. & 51.30 & 6. & \\
7. & Tertinggi & 8. & 86.67 & 9. & \\
10. & Terendah & 11. & 33.33 & 12. & \\
13. & Tuntas & 14. & 9 & 15. & 16.67 \\
16. & $\begin{array}{l}\text { Tidak } \\
\text { tuntas }\end{array}$ & 17. & 30 & 18. & 83.33 \\
\hline
\end{tabular}

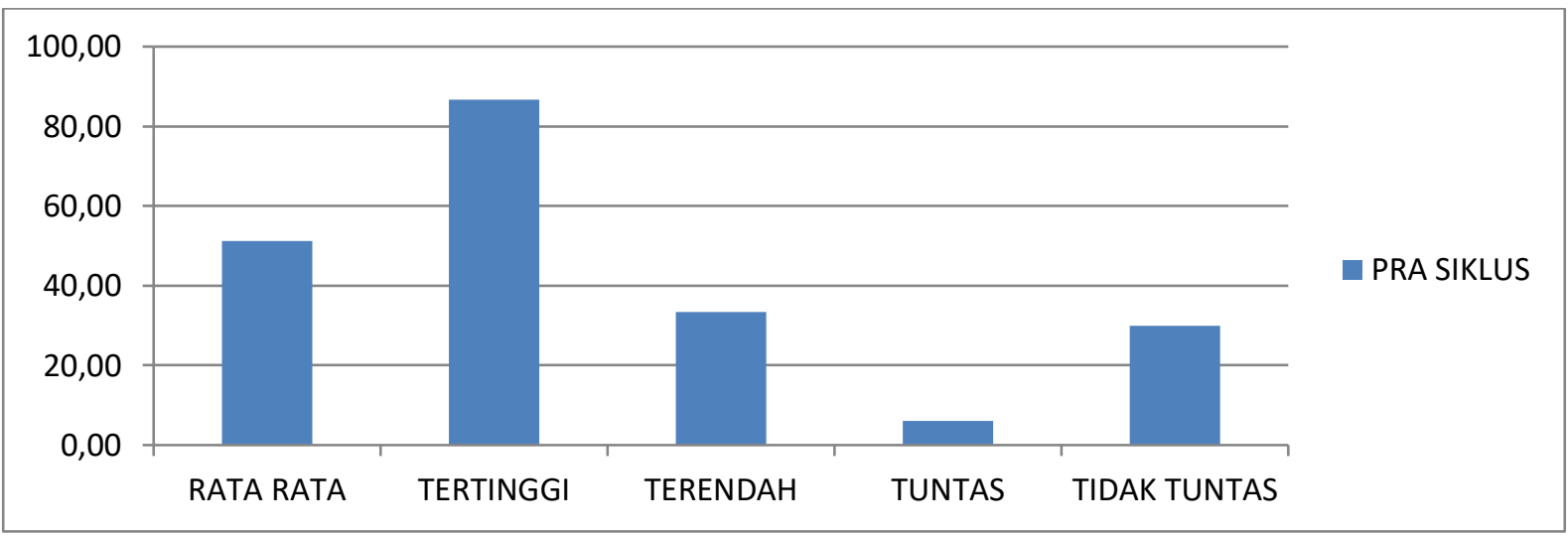

Diagram 1. Hasil Tes Tertulis Fisika pada Prasiklus

Pada tabel 3.1, Pada Siklus diketahui nilai rata-rata siswa masih dalam kategori kurang, yaitu sebesar 51,30. Siswa yang memperoleh nilai tertinggi sebesar 86,67 dan terendah 33,33. Yang sudah tuntas melampau KKM yang ditetapkan sebesar 70 adalah 9 orang atau 16,67\%. Selanjutnya sebanyak 30 siswa atau 83,33\% memperoleh nilai dibawah KKM. Hal tersebut menunujukkan bahwa kemampuan siswa dalam Fisika masih rendah dan perlu ditingkatkan.

\subsection{Deskripsi Hasil Belajar Fisika Pra Siklus}

Rendahnya minat belajar siswa berpengaruh pada hasil belajar siswa. Berdasarkan catatan hasil tersebut secara umum masih dibawah KKM. Dari kondisi awal itu dapat disimpulkan bahwa siswa kelas X MIPA 2 SMA Negeri 1 Ngemplak Boyolali tahun pelajaran 2019/2020 yang belum mampu mencapai KKM masih tergolong cukup besar.

\subsection{Deskripsi Hasil Siklus 1}

Kegiatan siklus I merupakan tindakan lanjutan setelah melihat data yang diperoleh pada prasiklus. Kegiatan pembelajaran siklus I dilaksanakan dengan menerapkan pembelajaran daring menggunaan LMS google classroom dalam pembelajaran Fisika. Pemaparan hasil penelitian siklus I diawali dengan memaparkan hasil prestasi belajar Fisika berupa perolehan nilai tes tertulis setelah siswa melaksanakan pembelajaran Fisika dengan menerapkan pembelajaran daring menggunaan LMS google classroom. Selanjutnya Proses Pembelajaran Fisika dengan menerapkan pembelajaran daring menggunaan LMS google classroom. Pada tahap awal pelaksanaan tindakan, guru membagikan pedoman yang telah dibuat dengan disertai pengantar sebagai berikut :

Pada tahap pendahuluan, peneliti memberikan apersepsi pembelajaran Fisika, ilustrasi tentang materi gerak harmonis, persiapan dan menyampaikan tujuan dan manfaat pembelajaran Fisika yang harus dicapai pada pertemuan itu.

Pada tahap kegiatan inti, peneliti melakukan kegiatan-kegiatan yang meliputi kegiatan menjelaskan kepada siswa bahwa dalam pembelajaran Fisika ini guru dengan menerapkan 
pembelajaran daring menggunaan LMS google classroom, menunjukkan dan menyiapkan siswa untuk diskusi, dan membimbing siswa untuk mengerjakan soal Materi Gerak Harmonis sesuai hasil diskusi dan lembar kerja siswa yang telah dibagikan dengan terlebih dahulu menjelaskan kriteria penilaian.

Pada tahap penutup, kegiatan pembelajaran Fisika ditutup dengan merefleksi hasil pembelajaran pertemuan itu. Guru memberi kesempatan pada siswa yang belum jelas untuk menanyakan materi Gerak Harmonis. Setelah selesai diskusi dan mengerjakan tugas, guru bersama membahas dan menyimpulkan hasil diskusi, kemudian semua tugas dikirimkan dan dikumpulkan, dan siswa bersiap untuk melaksanakan post test sesuai pengarahan awal. Selanjutnya hasil tes tertulis Fisika pada siklus I dijelaskan pada tabel 3.3.

Tabel 3. Hasil Tes Tertulis Fisika pada Siklus I

\begin{tabular}{lcc}
\hline & Siklus 1 & \% \\
\hline Rata rata & 72.59 & \\
Tertinggi & 100.00 & \\
Terendah & 53.33 & \\
Tuntas & 22 & 52.79 \\
Tidak tuntas & 17 & 47.22 \\
\hline
\end{tabular}

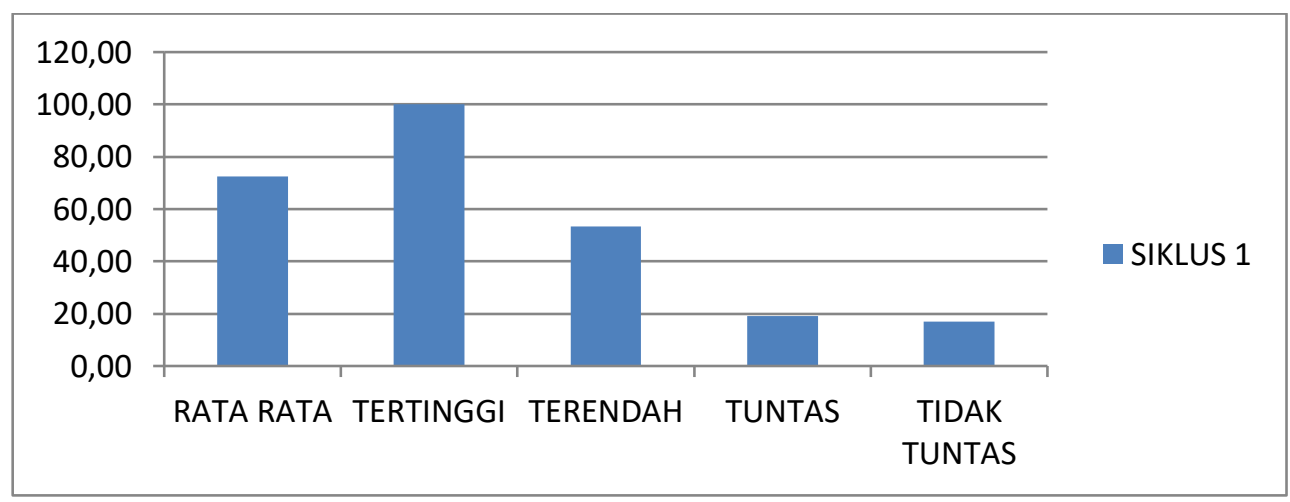

Diagram 3. Hasil Tes Tertulis Fisika pada Siklus 1

Pada tabel 3.3, diketahui nilai rata-rata siswa sudah dalam kategori cukup, yaitu sebesar 72,59. Siswa yang memperoleh nilai tertinggi sebesar 100,00 dan terendah 53,33. Siswa yang mencapai ketuntasan atau yang memperoleh nilai sama atau lebih dari KKM yang ditentukan yaitu 70 ada 22 siswa atau 52,79\%.

\subsection{Refleksi Siklus 1}

Refleksi siklus I dilakukan berdasarkan hasil tes pembelajaran Fisika pada materi Gerak Harmonis dengan menerapkan pembelajaran daring menggunaan LMS (google classroom) yang terlaksana pada siklus I. Berdasarkan hasil tes tertulis pada siklus I dapat disimpulkan adanya peningkatan dibandingkan hasil tes prasiklus. Peningkatan hasil Fisika pada siklus I menunjukkan penerapan pembelajaran daring menggunaan LMS (google classroom) pada materi Gerak Harmonis sudah cukup efektif bagi sebagian siswa. Namun, belum semua siswa memahami sepenuhnya penerapan pembelajaran daring menggunaan LMS (google classroom) pada materi Gerak Harmonis tersebut. Namun kondisi tersebut belum mencapai standar indikator kinerja yang telah ditentukan. Melihat hasil tersebut diatas maka menjadi refleksi bagi guru sebagai peneliti untuk memperbaiki pembelajaran pada siklus II. Guru menyusun rencana perbaikan yang akan dilaksanakan pada pembelajaran Fisika dengan menerapkan pembelajaran 
daring menggunaan LMS (quiper) siklus II untuk mengatasi berbagai kekurangan yang terjadi pada siklus I. Perbaikan yang dilakukan guru adalah menyusun rencana pembelajaran yang lebih sistematis, memberikan lebih rinci tentang penerapan pembelajaran daring menggunaan LMS (quiper), memberikan perhatian yang lebih besar kepada siswa yang masih belum tuntas. Hasil refleksi tersebut sebagai acuan untuk memperbaiki hasil pada siklus II, sehingga hasil yang dicapai lebih maksimal. Perbaikan-perbaikan tersebut diharapkan dapat meningkatkan prestasi belajar siswa dalam Fisika pada pembelajaran siklus II. Dengan demikian, hasil penelitian yang ditargetkan dapat tercapai secara maksimal.

\subsection{Deskripsi Hasil Siklus 2}

Deskripsi hasil penelitian pada siklus II diuraikan sebagai berikut. Pada tahap ini peneliti melakukan perbaikan-perbaikan proses pembelajaran sesuai hasil refleksi siklus I, dengan tahapan proses sebagai berikut. Pada tahap pendahuluan, peneliti memberikan apersepsi pembelajaran Fisika, dengan mengingat kembali materi Gerak Harmonis serta menyampaikan tujuan dan manfaat pembelajaran Fisika sesuai tujuan pada pertemuan itu dengan menggunakan LMS (quiper). Pada tahap kegiatan inti, peneliti melakukan kegiatan-kegiatan literasi membaca materi dengan menggunakan LMS (quiper), selanjutnya siswa diberi materi Gerak Harmonis, menjelaskan bahwa dalam pembahasan topik tersebut mendiskusikan, menjelaskan serta mempresentasikannya secara daring sesuai topik pembahasan, siswa yang mempresentasikan hasil diskusi diambil secara acak sehingga semua harus menyiapkan materi secara detail tentang topik yang dibahas, menunjukkan dan menyiapkan siswa untuk diskusi secara daring, mengumumkan hasil nilai dari siklus I kepada semua siswa, memberikan rambu-rambu penilaian yang dianggap bisa meningkatkan kemampuan siswa dan membimbing siswa terutama yang belum tuntas untuk mengerjakan soal materi Gerak Harmonis.

Pada tahap penutup, kegiatan pembelajaran Fisika ditutup dengan merefleksi hasil pembelajaran pertemuan itu. Guru memberi kesempatan pada siswa yang belum jelas untuk menanyakan materi materi Gerak Harmonis. Setelah selesai mengerjakan tugas, guru bersama siswa membahas dan menyimpulkan hasil dan siswa bersiap untuk melaksanakan post test sesuai pengarahan awal.

Hasil tes tertulis Siswa kelas X MIPA 2 SMA Negeri 1 Ngemplak Boyolali Fisika pada siklus II dijelaskan pada tabel 3.5

Tabel 5. Hasil Tes pada Siklus II

\begin{tabular}{lcc}
\hline & Siklus 2 & $\%$ \\
\hline Rata Rata & 83.52 & \\
\hline Tertinggi & 100.00 & \\
\hline Terendah & 66.67 & \\
\hline Tuntas & 37 & 94.44 \\
\hline Tidak Tuntas & 2 & 5.56 \\
\hline
\end{tabular}




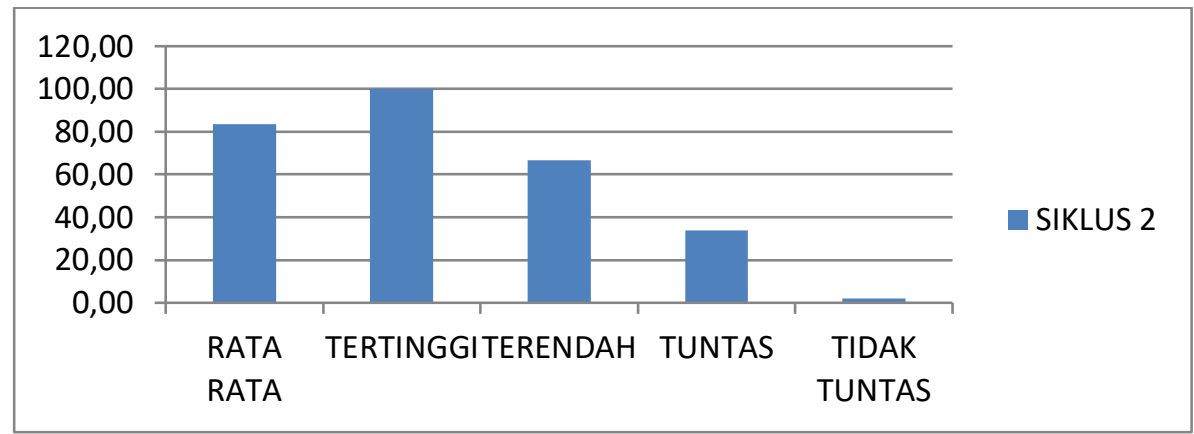

Diagram 3.5 Hasil Tes pada Siklus II

Berdasarkan data pada tabel 3.5, diketahui nilai rata-rata siswa mencapai kategori baik, yaitu sebesar 83,52 Siswa yang memperoleh nilai tertinggi sebesar 100,00 dan terendah 66,67. Terdapat 37 siswa yang memperoleh nilai mencapai ketuntasan atau memperoleh nilai sama atau lebih dari KKM yang ditentukan yaitu 70 atau sebanyak 94,44 \%. .

Hasil tes pada siklus II mengalami peningkatan dibandingkan hasil tes siklus I yaitu ratarata kelas berkategori cukup menjadi rata-rata kelas berkategori baik. Jika dibandingkan dengan hasil tes siklus I, hasil tes siklus II mengalami peningkatan sebesar 12,59 atau sebesar 19,26 \% yaitu dari 72,59 menjadi 83,52. Sebanyak 37 Siswa kelas X MIPA 2 SMA Negeri 1 Ngemplak Boyolali dari yang berjumlah 39 siswa pada siklus II telah mencapai nilai KKM. Selanjutnya dapat terlihat sudah cukup efektif dan terlihat peningkatan prestasi belajar Fisika pada siklus II dengan menerapkan pembelajaran daring menggunaan LMS (quiper) pada materi Gerak Harmonis siswa kelas X MIPA 2 SMA Negeri 1 Ngemplak Boyolali Semester Genap Tahun pelajaran 2019/2020.

\section{PEMBAHASAN}

Penelitian tentang Penerapan pembelajaran daring menggunaan LMS (google classroom dan quiper) untuk Meningkatkan Prestasi belajar Fisika Siswa Kelas X MIPA 2 SMA Negeri 1 Ngemplak Boyolali Semester Genap Tahun Pelajaran 2019/2020 yang dilakukan peneliti menunjukkan hasil yang memuaskan. Prestasi belajar Fisika siswa mengalami peningkatan setelah dilakukan tindakan pembelajaran dengan menerapkan pembelajaran daring menggunaan LMS (google classroom dan quiper), seperti terlihat pada tabel 4.4 berikut.

Tabel 6. Rekapitulasi Hasil Penelitian

\begin{tabular}{crrrrrrr}
\hline & $\begin{array}{c}\text { Pra } \\
\text { siklus - } \\
\text { siklus 1 }\end{array}$ & \multicolumn{2}{c}{$\begin{array}{c}\text { Siklus 1- } \\
\text { siklus 2 }\end{array}$} & $\%$ & $\begin{array}{c}\text { Pra siklus } \\
\text { - siklus 2 }\end{array}$ & $\%$ \\
\hline Rata rata & 21.29 & 41.50 & 10.93 & 15.06 & 32.22 & 62.81 \\
\hline Tertinggi & 13.33 & 15.38 & 0.00 & 0.00 & 13.33 & 15.38 \\
\hline Terendah & 20.00 & 60.01 & 13.34 & 25.01 & 33.34 & 100.0 \\
\hline Tuntas & 13.00 & 36.11 & 15.00 & 41.67 & 28.00 & 77.78 \\
\hline
\end{tabular}




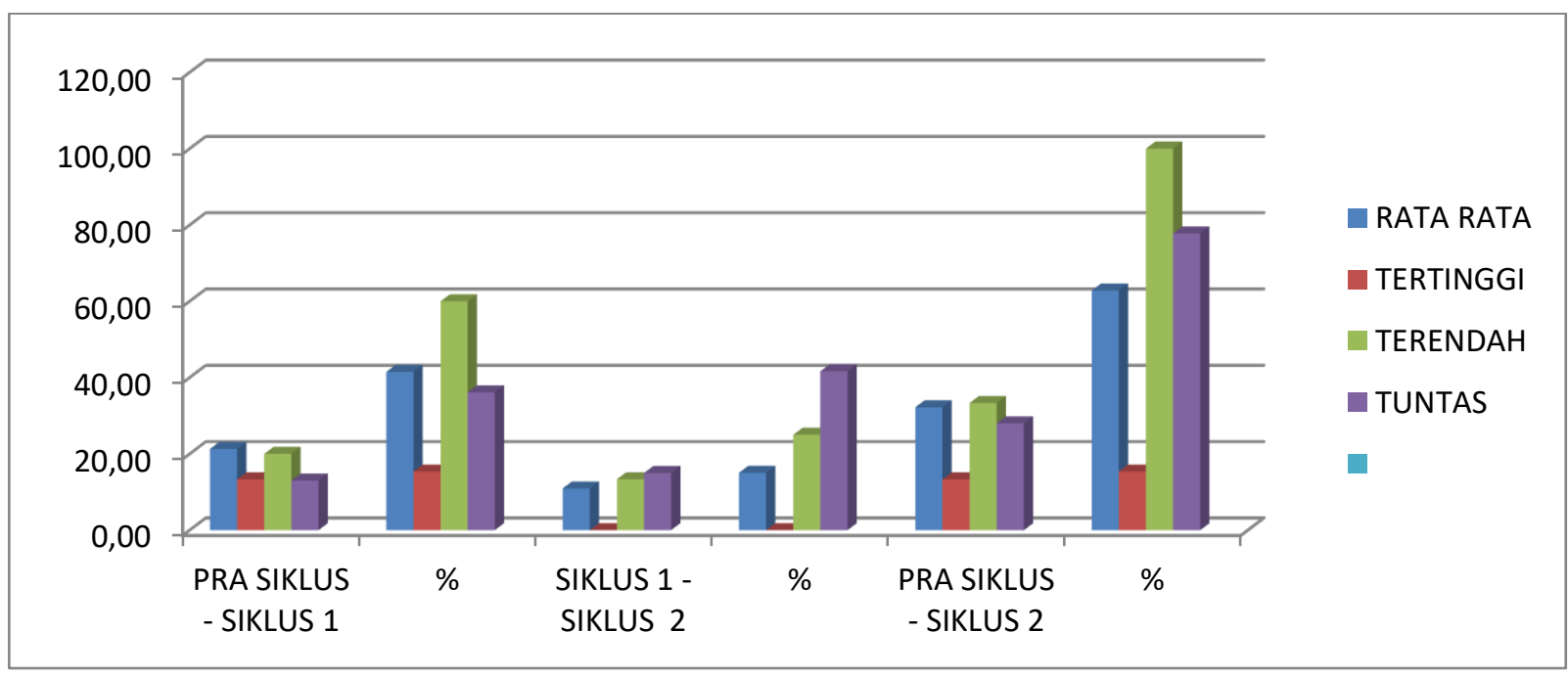

Diagram 6. Rekapitulasi Hasil Penelitian

Berdasarkan tabel 3.6 terlihat adanya peningkatan setelah dilakukan tindakan pembelajaran Fisika dengan menerapkan pembelajaran daring menggunaan LMS (google classroom). Nilai rata-rata kelas pada prasiklus hanya mencapai 51,30 setelah dilaksanakan pembelajaran Fisika dengan menerapkan pembelajaran daring menggunaan LMS (quiper) pada siklus I dan siklus II, kemampuan Fisika siswa mengalami peningkatan yang sangat memuaskan dan sudah memenuhi target penelitian.

\section{SIMPULAN}

Penerapan pembelajaran daring menggunaan LMS (google classroom dan quiper) untuk meningkatkan prestasi belajar Fisika pada siswa kelas X MIPA 2 SMA Negeri 1 Ngemplak Boyolali semester Genap tahun pelajaran 2019/2020 mengalami peningkatan. Nilai rata-rata siswa pada siklus I mengalami peningkatan sebesar 20,56 atau 45,87\% . yaitu dari 51,30 menjadi 72,59 dan mengalami peningkatan lagi pada siklus II sebesar 12,59 atau sebesar 19,26\% yaitu 72,59 menjadi 83,52, dan termasuk dalam kategori baik. Peningkatan nilai ratarata tersebut membuktikan keberhasilan pembelajaran Fisika dengan menerapkan pembelajaran daring menggunaan LMS (google classroom dan quiper) pada materi Gerak Harmonis.

\section{SARAN}

Berdasarkan simpulan penelitian tersebut, maka saran yang diberikan oleh peneliti adalah sebagai berikut.

1. Guru mata pelajaran hendaknya menerapkan pembelajaran daring menggunaan LMS (google classroom dan quiper) dalam memberikan materi Fisika, karena dengan menerapkan pembelajaran daring menggunaan LMS (google classroom dan quiper) terbukti dapat meningkatkan prestasi belajar Fisika.

2. Penerapan pembelajaran daring menggunaan LMS (google classroom dan quiper) dapat digunakan sebagai alternatif pemilihan model pembelajaran karena memiliki keunggulan merangsang berpikir kritis, berdisiplin, bekerjasama dengan siswa lain, mencari solusi sesuai masalah yang dihadapi.

3. Para peneliti yang menekuni bidang penelitian tindakan kelas dapat melakukan penelitian lanjutan mengenai prestasi belajar Fisika. Hasil penelitian tersebut diharapkan dapat membantu guru dalam memecahkan masalah yang sering muncul dalam proses 
pembelajaran di kelas sehingga berdampak positif bagi perkembangan pendidikan yang lebih berkualitas.

\section{DAFTAR PUSTAKA}

Djamarah, Bahri, Syaiful, 2000, Guru dan Anak Didik dalam Interaksi Edukatif, Jakarta : PT Rineke Cipta

Hamalik, Oemar, 2008. Kurikulum dan Pembelajaran, Jakarta :Bumi Aksara

Ibrahim, Muslimin, dkk, 2000,Pembelajaran Kooperatif. Surabaya: University Press.

Kasdi, S. Dan Muhammad Nur, 2000,Pengajaran Langsung. Surabaya: University Press.

Muntasir, Saleh, 1985, Pembelajaran Terprogram, Yogyakarta: Karya Anda

Muntasir, Saleh, 2006, Strategi Belajar Mengajar, Jakarta:PT Rineke Cipta.

Nana Sudjana, Ahmad, 1991, Dasar-dasar Proses Belajar Mengajar, Bandung: Sinar Baru.

Sartono, Bangun, 2019, Penerapan Model Pembelajaran Discovery Learning Berbantuan Lembar Kerja Siswa Untuk Meningkatkan Prestasi Belajar Fisika Materi Fluida Pada Siswa Kelas Xi Mipa 3 SMA Negeri 1 Ngemplak Boyolali Semester Ganjil Tahun Pelajaran 2018/2019, Prosiding SNFA (Seminar Nasional Fisika dan Aplikasinya).

Sartono, Bangun, dkk, 2014, Karakterisasi Kelistrikan Kaca 60TeO2-(30-x)ZnO-x Na2 CO3 yang Dikristalkan Sebagian, Prosiding Mathematics And Sciences Forum .

Sartono, Bangun, 2017, Penerapan Metode Tutor Sebaya Untuk Meningkatkan Prestasi Belajar Fisika Materi Gerak Rotasi Dan Kesetimbangan Benda Tegar Pada Siswa Kelas XI MIPA 3 SMA Negeri 1 Ngemplak Boyolali Semester Ganjil Tahun Pelajaran 2017/2018, Jurnal WESRIQAD (Jurnal Kependidian).

Semiawan Cony, 1990. Pendekatan Prestasi belajar Proses, Jakarta: PT Gramedia

Subyantoro,2009, Penelitian Tindakan Kelas, Semarang: CV.Widya Karya.

Supardi, Suharjono. 2011.Strategi Menyusun Penelitian Tindakan Kelas, Yogyakarta : Andi Offset.

Sudjana, Nana.1989. Penilaian Hasil Proses Belajar Mengajar, Bandung: Remaja Rosdakarya.

Trianto, 2007,Model-model Pembelajaran Inovatif Berorientasi Konstruktivistik. Surabaya: Prestasi Pustaka Publisher.

Warji dan Ischak, 1987. Program Remedial dalam Proses Belajar Mengajar : Jakarta : Gramedia. 